\title{
Assessment of welfare indicators in grazing dairy cows in Northeast Brazil
}

\section{Avaliação de indicadores de bem-estar em vacas leiteiras a pasto no Nordeste do Brasil}

\author{
Severino Guilherme Caetano Gonçalves dos Santos ${ }^{1 *}$; Edilson Paes Saraiva ${ }^{2}$; \\ Vinícius de França Carvalho Fonsêca ${ }^{2}$; Carla Aparecida Soares Saraiva ${ }^{3}$; Severino \\ Gonzaga Neto ${ }^{3}$; Sérgio da Silva Fidelis ${ }^{4}$; Mikael Leal Cabral Menezes de Amorim ${ }^{5}$; \\ José Danrley Cavalcante dos Santos ${ }^{5}$
}

\section{Highlights:}

Welfare of grazing dairy cows on small-scale farms.

Pasture cows showed a high prevalence of bodily injuries.

Dirt in cows is an indicator of inadequate hygiene and comfort.

Body expressions as a tool for assessing animal welfare.

\begin{abstract}
The welfare of dairy cows is a major global concern, due to its impact on cow health and productivity, as well as public health. The aim of this study was to identify the main problems related to welfare in dairy herds managed on pasture in the state of Paraíba, Brazil. For this investigation, a cross-sectional study was conducted in 12 dairy farms in the municipalities of Areia, Alagoa Grande, Serraria, and Pilões, Paraíba, Brazil. Each farm was visited only once, recording the number of cows in the herd, type and number of milkings per day, daily milk yield, and access time to the pasture. Body condition score, cleanliness score, bodily injuries, and qualitative behavioral assessment (QBA) were measured. A total of 335 dairy cows were evaluated; herds ranged from 14 to 43 lactating cows, with an average milk yield of $8.4 \pm 3.25 \mathrm{~kg}$ day $^{-1}$. Of the 335 cows observed, $26 \%$ had a low body condition score, $82 \%$ had bodily injuries, and $20 \%$ had dirt on their legs. For the QBA, a principal component analysis (PCA) indicated that PC1 had a high correlation mainly with positive body expressions (e.g., sociable, active, and happy), and PC2 was associated with negative terms of body expression (e.g., apathetic, frustrated, and fearful). In conclusion, evaluating indicators of cows' body condition, bodily injury, and cleanliness highlighted the importance of promoting improvements in pasture, management, and housing conditions to enable better performance, health, and welfare of the animals.
\end{abstract}

Key words: Qualitative behavior assessment. Body hygiene. Animal health.

1 Pesquisador, Instituto Nacional do Semiárido, INSA, Campina Grande, PB, Brasil. E-mail: guilhermeufpb@gmail.com

2 Profs., Grupo de Estudos em Bioclimatologia, Etologia e Bem-Estar Animal, BIOET, Departamento de Zootecnia, Centro de Ciências Agrárias, Universidade Federal da Paraíba, UFPB, Areia, PB, Brasil.E-mail: edilson@cca.ufpb.br; vinicius_fonseca86@ hotmail.com

3 Profs., Departamento de Zootecnia, Centro de Ciências Agrárias, UFPB, Areia, PB, Brasil. E-mail: carla.ap.soares@gmail.com; sgonzaganeto@gmail.com

4 Discente, Curso de Zootecnia, Centro de Ciências Agrárias, UFPB, Areia, PB, Brasil. E-mail: sergio fidelis@outlook.com

5 Discentes, Programa de Doutorado Integrado em Zootecnia, Centro de Ciências Agrárias, UFPB, Areia, PB, Brasil. E-mail: mikael_leal@hotmail.com; danrleyczootecnia@gmail.com

* Autthor for correspondence 


\title{
Resumo
}

\begin{abstract}
O bem-estar de vacas leiteiras é uma preocupação global, devido ao seu impacto na saúde e produtividade das vacas, bem como na saúde pública. O objetivo deste estudo foi identificar os principais problemas relacionados ao bem-estar em rebanhos leiteiros manejados a pasto no estado da Paraíba, Brasil. Para esta investigação, foi realizado um estudo transversal em 12 fazendas leiteiras nos municípios de Areia, Alagoa Grande, Serraria e Pilões, Paraíba, Brasil. Cada fazenda foi visitada apenas uma vez, registrandose o número de vacas do rebanho, tipo e número de ordenhas por dia, produção diária de leite e tempo de acesso à pastagem. Escore de condição corporal, escore de limpeza, injúrias corporais e avaliação qualitativa do comportamento (AQC) foram medidos. Um total de 335 vacas leiteiras foram avaliadas; os rebanhos variaram de 14 a 43 vacas em lactação, com produção média de leite de $8,4 \pm 3,25 \mathrm{~kg} \mathrm{dia}^{-1}$. Das 335 vacas observadas, $26 \%$ apresentaram baixo escore de condição corporal, $82 \%$ sofreram injúrias corporais e $20 \%$ apresentaram sujeira nas pernas. Para o AQC, uma análise de componentes principais (ACP) indicou que o $\mathrm{CP} 1$ teve alta correlação com expressões corporais positivas (por exemplo, sociável, ativo e contente), e CP2 foi associado a termos negativos de expressão corporal (por exemplo, apático, frustrado e com medo). Em conclusão, a avaliação de indicadores da condição corporal das vacas, injúrias corporais e limpeza destacou a importância de promover melhorias nas pastagens, manejo e condições de alojamento para permitir melhor desempenho, saúde e bem-estar dos animais.
\end{abstract}

Palavras-chave: Avaliação qualitativa do comportamento. Higiene corporal. Saúde animal.

\section{Introduction}

Concern for the welfare of dairy cows has been growing in recent years, due to its impact on the health and productivity of cows, as well as on public health. Consumers are increasingly aware of the impact of dairy cows' welfare on public health, the safety of dairy products, and environmental protection. As a result, consumers are advised to buy products from animals whose "welfare is not threatened" and who are reared on farms that comply with good practice standards (Broom \& Fraser, 2010). This is a reality that goes beyond the barriers of large dairy industries it also reaches medium and small farms because the issue of animal welfare is a global movement.

An individual's welfare is his or her state relative to his or her attempts to adapt to his or her environment (Broom \& Fraser, 2010), considering physical, physiological, and emotional aspects related to the health condition. Assessing welfare should preferably utilize a wide variety of measures. Although a single measure may indicate whether welfare is poor, studies comparing welfare in different systems, or using different methods of production, should be based on a set of indicators (Whay, Main, Green, \& Webster, 2003). For example, the Welfare Quality ${ }^{\circledR}$ (2009) protocol applied to dairy cattle is used in several countries; this protocol, as well as others (Popescu, Borda, Sandru, Stefan, \& Lazar, 2010), is based on four fundamental criteria: feeding, housing, health, and animal behavior. Feeding and housing directly (positively or negatively) affect animal welfare. Inadequate housing and feeding expose animals to numerous stressors and unpleasant emotions, which affect the occurrence of diseases, injuries, and behavioral disorders (Broom \& Fraser, 2010; Matthews, Cameron, Sheahan, Kolver, \& Roche, 2012).

Several studies have been conducted to assess the welfare of cows in housing conditions (Andreasen, Wemelsfelder, Sandøe, \& Forkman, 2013; Cook, Hess, Foy, Bennett, \& Brotzman, 2016) and in grazing (Burow, Thomsen, Rousing, \& Sørensen, 2013; Wagner et al., 2018). Studies in housed herds have specified a high prevalence of cows with bodily injuries (hocks and knees injuries), lameness, and mastitis (Chapinal, Barrientos, 
von Keyserlingk, Galo, \& Weary, 2013; Zaffino Heyerhoff et al., 2014). Investigations suggest that cows with access to pasture experience a greater repertoire of positive experiences, such as a lower incidence of injuries, mastitis, dirt on their body, and agonistic behaviors (Sant'Anna \& Paranhos da Costa, 2011; Kivling, 2012; Wagner et al., 2018). However, pasture-based systems can also present risk factors that compromise the welfare of cows, such as management, path conditions, access distances to the pasture, and even the quality of the pasture (Burow et al., 2014; Ranjbar, Rabiee, Gunn, \& House, 2016; Bran, Daros, von Keyserlingk, LeBlanc, \& Hötzel, 2018).

It is worth mentioning that most of the aforementioned studies were conducted in Europe and North America, where research on animal welfare is well advanced. In Brazil, studies carried out to assess the welfare of dairy cows are incipient (Sant'Anna \& Paranhos da Costa, 2011; Bran et al., 2018; Costa, Burnett, von Keyserlingk, \& Hötzel, 2018); they have mainly considered herds managed on pastures (Garcia, 2013; Santos et al., 2017). In addition, Brazilian studies have concentrated on herds in the South and Southeast regions; thus, there is a need to diagnose and evaluate herd welfare indicators in other Brazilian regions to assist producers, develop assessment protocols adjusted to the reality of each region, and propose adjustments to welfare codes and current legislation. In this context, the objective of this study was to identify the main problems related to welfare in dairy herds managed on pasture on Northeast Brazilian farms.

\section{Material and Methods}

\section{Local and study population}

A cross-sectional study was conducted on dairy farms in the municipalities of Areia, Alagoa Grande, Serraria, and Pilões in the state of Paraíba, Brazil, between January and June 2017. All procedures were approved by the Ethics Committee on the Use of Animals of the Federal University of Paraíba
(Protocol $n^{\circ}$ 105/2017). The components of the target population were dairy cows in herds larger than 10 lactating cows and cows kept in pasture areas. A necessary criterion to participate in the study was herds that spent a minimum of 240 days year ${ }^{-1}$ and 5 hours day ${ }^{-1}$ pasture access (this management must have been followed in the 30 days prior to the visit to the farm). In the other periods, the cows received feed via a feeder.

\section{Farm selection}

The farm sample was selected through recruited farmers based on information provided by farmers' associations and people working in the region's dairy sector. To minimize selection trends, the informants were only aware of the general objective of the study. Fifteen small-scale dairy farms were preselected. At the first contact, by phone or in person, the producer was informed of the research and voluntarily declared whether he or she would participate. Twelve producers agreed to participate in the study; three producers refused and were removed from the database.

\section{Data recording and herd observation}

At participating farms $(\mathrm{n}=12)$, visits were scheduled and occurred between $08 \mathrm{~h} 00$ and $14 \mathrm{~h} 00$. The number of cows in the herd, type and number of milkings per day, daily milk yield, and pasture access time were recorded after interviewing the farmer or farm manager and consulting control sheets (Welfare Quality ${ }^{\circledR}, 2009$ ). In addition, the type of surface of the facilities (waiting corral, feeder, and rest areas) on each farm was visually assessed.

Observations in all herds were carried out by observers in the area of ethology and animal welfare; these individuals had been trained with photos and videos of situations similar to those in the field. Each herd was evaluated only once. The cow selection order within the herds was made 
by random sampling, ensuring that all cows were observed (Welfare Quality ${ }^{\circledR}, 2009$ ). Observations were conducted at times and places where the cows were most relaxed (for example, resting pens, shade, and woods), to facilitate the observer's approach.

\section{Measures based on the animal}

Body condition score (BCS). The animals were not touched, only observed. Four body regions (cavity around the top of the tail; loin; vertebrae; top of the tail, hipbones, spine and ribs) of each animal were observed in full and scored: BCS $0=\operatorname{good}$ corporal condition; BCS $1=$ lean cow; and BCS $2=$ fat cow (Welfare Quality ${ }^{\circledR}, 2009$ ).

Cleanliness score. Each cow was evaluated on one side of the body (random selection) and behind. Two types of dirt on the cow's body parts were considered: splashing (e.g., feces and mud) and plaques (three-dimensional layers of dirt amounting to the size of the palm, or if more than half of the area under consideration is covered). The lower part of the hind legs (including the hock), the hind quarters, the upper part of the rear legs, flank, and rear including the tail (excluding the udders), and the udder were observed and scored $(0=$ No dirt; 1 $=$ With dirt) (Welfare Quality $\left.{ }^{\circledR}, 2009\right)$.

Bodily injuries. Several body regions neck/ shoulder/back, knee, flank/side/udder, hock, and hind quarters-were scored for hairless spots $(0$ $=$ does not occur; $1=$ occurs $)$, lesions $(0=$ does not occur; $1=$ occurs $)$, and swelling $(0=$ does not occur; 1 = occurs). Hairless spots were considered as areas with lost hair and undamaged skin; lesions as damaged skin, whether in the form of a scab or a wound and amputations; and swelling as abnormal skin bulge with or without hair (Welfare Quality ${ }^{\circledR}$, 2009).

Qualitative Behavior Assessment (QBA). QBA considers the expressive quality of how animals behave and interact with each other and with the environment, that is, their "body language."
A set of 20 qualitative terms/descriptors was used for the group of dairy cows at QBA: active, frustrated, irritable, relaxed, friendly, uneasy, fearful, bored, sociable, agitated, playful, apathetic, calm, positively occupied, happy, content, lively, distressed, indifferent, and inquisitive (Welfare Quality $\left.^{\circledR}, 2009\right)$. All terms were connected to a visual analog scale (VAS) of $125 \mathrm{~mm}$, where the minimum and the maximum represent the extremes of the scale. Observers were instructed not to evaluate the cows individually, but to assess the interaction between the cows and the environment. The animals were evaluated in grazing areas for 60 consecutive minutes. After observing the animals, the evaluators went to a place where the dairy cows were not visible and scored using a VAS; only one integrative evaluation was carried out per farm. All QBA assessments were made between 09h00 and $12 \mathrm{~h} 00$, and observers were always dressed in the same type and color of clothing on all farms (Welfare Quality ${ }^{\circledR}, 2009$ ).

\section{Statistical analysis}

Descriptive analysis (mean, percentage, and standard deviation) was performed to describe the characteristics of the farms and cows with data based on records and interviews (milk yield, access time to pasture, and type of milking) and based on the animal (BCS, cleanliness, and bodily injuries). Based on the QBA terms, exploratory analyses were carried out through principal component analysis (PCA) to identify patterns of dissimilarity between herds. All data were analyzed using R statistical software (R Core Team [R], 2018).

\section{Results and Discussion}

The descriptive characteristics of the herds are shown in Table 1. A total of 335 dairy cows (Holstein $\times$ Zebu) were evaluated; herds ranged from 14 to 43 lactating cows. All farms used a mechanized milking system, with two milking per day. The average milk 
yield was $8.4 \pm 3.25 \mathrm{~kg}$ cow day ${ }^{-1}$. The access time to the pasture was 6-19 hours day ${ }^{-1}$ among herds. The floor surfaces of the housing were predominantly concrete and gross. According to Zoccal, Alves and
Gasques (2011), these typological characteristics are common in production units in Northeast Brazil, where milk production is predominantly carried out by family-based farmers.

\section{Table 1}

\section{Characteristics of dairy cow herds managed on pasture}

\begin{tabular}{lcccc}
\hline Farms & Cows $(\mathrm{n})$ & Milk yield $\left(\mathrm{kg} \mathrm{cow} \mathrm{day}^{-1}\right)$ & ${\text { Grazing time }\left(\mathrm{h} \mathrm{day}^{-1}\right)}^{-}$ & Housing floor \\
\hline 1 & 30 & 13.0 & 18 & concrete \\
2 & 32 & 8.0 & 8 & gross floor \\
3 & 23 & 12,0 & 6 & gross floor \\
4 & 18 & 8.0 & 8 & concrete \\
5 & 14 & 6.5 & 8 & concrete \\
6 & 20 & 5.6 & 11 & gross floor \\
7 & 37 & 12.2 & 18 & concrete \\
8 & 30 & 12.1 & 18 & gross floor \\
9 & 39 & 7.0 & 18 & gross floor \\
10 & 35 & 3.0 & 19 & gross floor \\
11 & 43 & 8.5 & 18 & concrete \\
12 & 14 & 5.0 & 18 & concrete \\
Mean \pm SD & $28 \pm 9.9$ & $8.4 \pm 3.2$ & $14 \pm 5.2$ & - \\
\hline
\end{tabular}

Table 2 shows the body condition evaluation of the studied herds. The majority $(72.33 \pm 17.3 \%)$ of the cows showed a good body condition; however, $25.83 \pm 16.4 \%$ were classified as lean, and only 1.84 $\pm 2.7 \%$ were fat. Farms 3, 4, 7, and 9, which had the highest percentage of cows in good body condition, were also the ones that kept the pasture in better condition (quality); on these farms, the pastures were predominantly Mombasa grass (Panicum maximum) or tifton (Cynodon spp.). By contrast, three farms $(5,10$, and 12) stood out for their limited pasture availability and low-quality grass (Brachiaria decumbens); this situation was possibly reflected in the high percentage of cows with a low body condition and the low milk yield observed in these herds. Studies suggest that very lean as well as very fat cows are at risk of having metabolic problems and diseases, reduced milk yield, and a lower rate of conception and difficulties at calving (Matthews et al., 2012; Sadiq, Ramanoon, Shaik Mossadeq, Mansor, \& Syed-Hussain, 2017).

When low body condition is associated with inadequate body reserves, animals experience malnutrition, which is regularly cited as one of the most important welfare problems for dairy herds (Sadiq et al., 2017). Skinny animals are presumed to suffer from poor welfare. Although the physiological evidence is scarce, a low BCS is associated with higher blood albumin concentrations in cattle (Strydom et al., 2008), a phenomenon that characterizes a chronic state of catabolism. 


\section{Table 2}

Body condition of dairy cows managed on pasture

\begin{tabular}{lcccc}
\hline \multirow{2}{*}{ Farms } & \multirow{2}{*}{ Cows (n) } & \multicolumn{3}{c}{ Body Condition (\% of cows) } \\
\cline { 3 - 5 } & 30 & Good body condition & Lean cows & Fat cows \\
\hline 1 & 32 & 73.33 & 26.67 & 0.00 \\
2 & 23 & 75.00 & 25.00 & 0.00 \\
3 & 18 & 86.96 & 8.70 & 4.35 \\
4 & 14 & 94.44 & 5.56 & 0.00 \\
5 & 20 & 64.29 & 35.71 & 0.00 \\
6 & 37 & 70.00 & 25.00 & 5.00 \\
7 & 30 & 86.49 & 13.51 & 0.00 \\
8 & 39 & 73.33 & 26.67 & 0.00 \\
9 & 35 & 82.05 & 17.95 & 0.00 \\
10 & 43 & 25.71 & 68.57 & 5.71 \\
11 & 14 & 72.09 & 20.93 & 6.98 \\
12 & $28 \pm 9.9$ & $72.33 \pm 17.3$ & 35.71 & 0.00 \\
Mean \pm SD & 335 & 241 & $25.83 \pm 16.4$ & $1.84 \pm 2.7$ \\
Total (n) & & & 87 & 7 \\
\hline
\end{tabular}

Of the 335 dairy cows observed, $267(81.50 \pm$ $12.3 \%$ ) presented injuries (hairless spot, swelling, or lesions) in any of the five evaluated body regions (Table 3). There was a high prevalence of injuries to the skin of the cows in all evaluated farms. The main injuries were swelling in the neck and hairless spots on the hock. The high prevalence of neck swelling is possibly associated with inappropriate management (location and type of injection, needles, and/or dosage) of vaccination (Cresswell, Remnant, Butterworth, \& Wapen, 2016). Hairless spots and lesions may have been caused by the physical conditions of the facilities, for example, abrasive floors or narrow access corridors with sharp surfaces (barbed wire); furthermore, inadequate pasture management may have resulted in uncovered and compacted soils. Therefore, the areas destined for grazing can be potential causal factors of injuries, as evidenced by the quality of the walking trails used by the cows to access the pastures and the distance traveled between the pasture and the milking parlor (Burow et al., 2014). These injuries to the integument can lead to pain in the animal that is similar to what occurs for locomotion disorders (Rushen, Haley, \& De Passillé, 2007). In addition, the high incidence of injuries to dairy cows, in addition to seriously impairing the animals' welfare, also causes great economic losses for farmers (Bruijnis, Hogeveen, \& Stassen, 2013).

Cows are more often exposed to agents that cause mastitis in the pasture, waiting rooms, and milking rooms. Waste management, the type and bed cleaning procedures, and cleaning the waiting room, milking environment, and pasture have a strong influence on the hygiene of the animals. In this way, the hygiene of dairy cows serves as an indicator of animal welfare and farm management efficiency (Ellis et al., 2007).

In the present study, cows with dirty lower legs were prevalent $(19.68 \pm 23.7 \%)$, followed by hindquarters $(7.77 \pm 14.3 \%)$ and dirty udders $(2.98$ $\pm 7.9 \%$ ) (Table 3 ). This result can be explained by the fact that this anatomical region is more exposed to environmental dirt, especially when cows use paths with accumulated mud. At farms 3 and 4, 
which had a higher incidence of dirty cows (legs, hindquarters, and flank), access to pasture was reduced compared with other farms, so these animals spent more time housed, a condition that favors waste accumulation. Hughes (2001) suggested that the degree of cleanliness of different anatomical regions can provide useful information to identify the causes of hygiene problems: dirty legs result from the accumulation of mud and problems in the way the cows travel; dirty tail may be related to the accumulation of feces; dirty hindquarters and flanks with accumulation of dirt indicate problems with the bed or place where the animals lay; and dirty teats and udders result from the combination of all these factors.

Table 3

Percentage of cows with bodily injury and dirty in herds managed on pasture

\begin{tabular}{lccccc}
\hline \multirow{2}{*}{ Farms } & Cows $(\mathrm{n})$ & $\begin{array}{c}\text { Bodily injury } \\
(\% \text { of cows) }\end{array}$ & Lower hind legs & Hindquarters and flank & Udder \\
\cline { 4 - 6 } & 30 & 90.00 & 10.00 & 3.33 & 0.00 \\
2 & 32 & 87.50 & 0.00 & 6.25 & 0.00 \\
3 & 23 & 73.90 & 21.74 & 17.39 & 0.00 \\
4 & 18 & 88.90 & 88.89 & 50.00 & 27.78 \\
5 & 14 & 92.90 & 21.43 & 0.00 & 0.00 \\
6 & 20 & 10.00 & 25.00 & 0.00 & 0.00 \\
7 & 37 & 86.50 & 18.92 & 10.81 & 5.41 \\
8 & 30 & 76.70 & 23.33 & 0.00 & 0.00 \\
9 & 39 & 69.20 & 15.38 & 2.56 & 2.56 \\
10 & 35 & 85.70 & 11.43 & 2.86 & 0.00 \\
11 & 43 & 55.80 & 0.00 & 0.00 & 0.00 \\
12 & 14 & 71.40 & 0.00 & 0.00 & 0.00 \\
Mean \pm SD & $28 \pm 9.9$ & $81.50 \pm 12.3$ & $19.68 \pm 23.7$ & $7.77 \pm 14.3$ & $2.98 \pm 7.9$ \\
\hline Total (n) & 335 & 267 & 56 & 22 & 8 \\
\hline
\end{tabular}

It is worth noting that the observations made in this study were between January and June, traditionally the rainiest months in the region; this factor possibly compromised the hygiene of the cows. In a study with dairy cows in Southeast Brazil, Sant'Anna and Paranhos da Costa (2011) reported that the most critical months for the cows' hygiene were those with the highest rainfall, when there was a reduction in the cows' welfare and high somatic cell count values in milk.

In Brazil, most dairy cows are kept in pasture systems on small and medium farms (Vilela, Resende, Leite, \& Alves, 2017), so it can be assumed that the welfare of these animals is better than those kept in an intensive production system (Cardoso, von Keyserlingk, \& Hötzel, 2017). While it is not possible to know how an animal feels, the QBA provides an assessment of the animal's complete response to its environment and what is happening to it. QBA, therefore, measures "results" and contributes to the welfare assessment because it can capture variations in the way animals respond and deal with their environment at that moment (Fleming et al., 2016).

The exploratory analysis showed a pattern of separation into four distinct groups (group 1 
gathered farms $1,2,3,4,6,7,8,9$, and 11; group 2 included farm 5; group 3 included farm 10; and group 4 included farm 12) (Figure 1). The farms in group 1 showed a greater relationship with $\mathrm{CP} 1$ (positive body expressions, $\mathrm{P}<0.001$ ), while groups 2, 3, and 4 were associated with CP2 (negative body expressions, $\mathrm{P}<0.001)$ (Table 4). From the analysis of principal components (accumulated variance $=$ $67 \%$ ), at most farms (group 1), the cows showed positive body expressions (e.g., sociable, active, happy, content, playful, positively occupied, and inquisitive), which may be associated with greater availability of forage on these farms. By contrast, a greater number of animals on farms 5, 10, and 12 were in a negative emotional state (e.g., apathetic, frustrated, agitated, bored, and fearful). Considering an integrated assessment, these findings suggest that negative body expressions are linked to a low BCS, possibly due to the low quality of the pasture, a fact that increases negative experiences (Mellor, 2016). Hogan and Phillips (2008) reported that in terms of emotional responses, low body condition is likely to lead to - at a minimum - frustration and exhaustion, as well as possible problems arising from associated diseases.

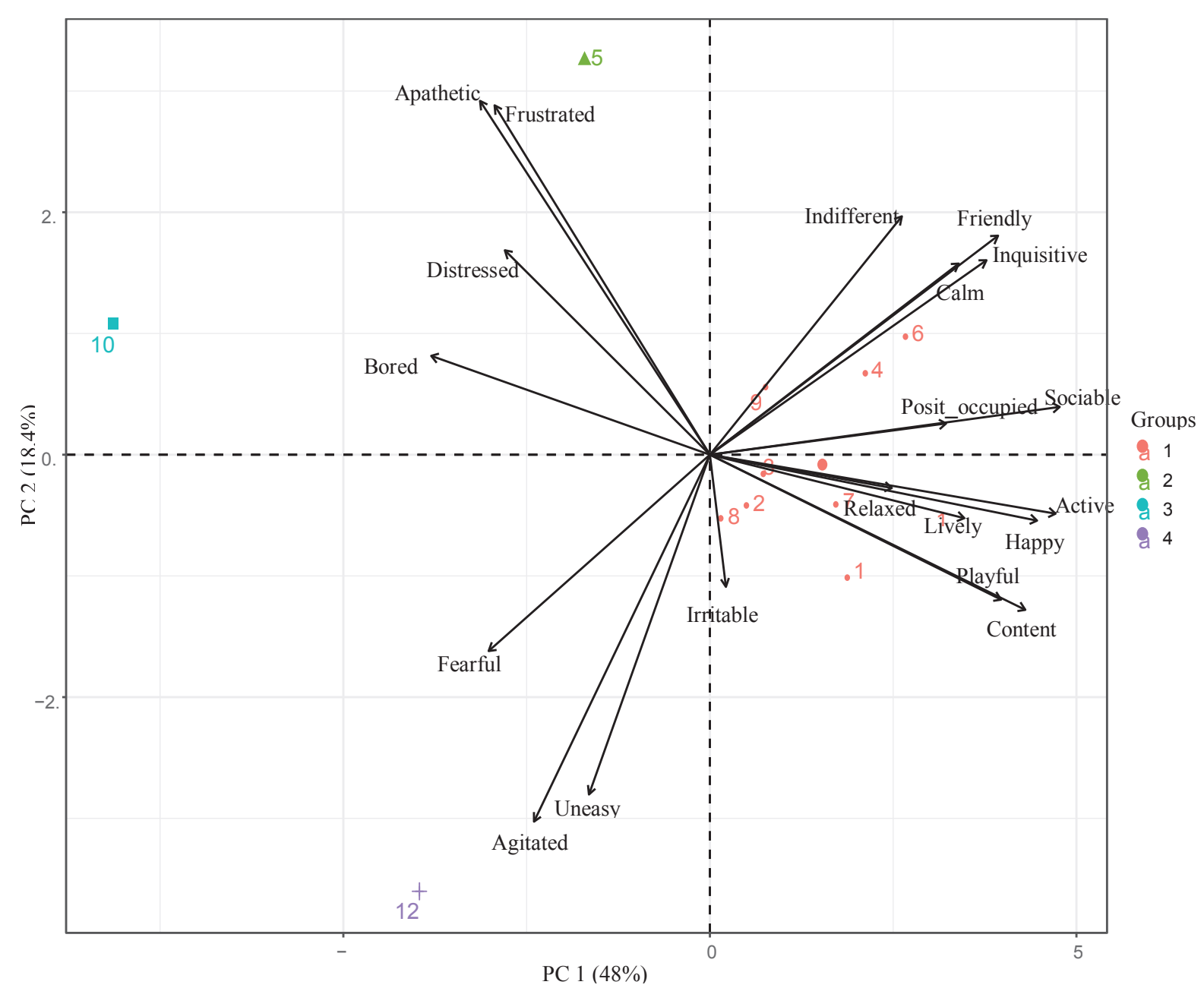

Figure 1. Diagram of the distribution of farm groups $(n=12)$ based on the 20 fixed terms of the predefined QBA of the Welfare Quality ${ }^{\circledR}$ protocol, analyzed using PCA. 
Table 4

Description of principal components 1 and 2

\begin{tabular}{cccc}
\hline Principal component & Terms & Correlation & $\mathrm{P}$ value \\
\hline & Sociable & 0.965 & $\mathrm{P}<0.001$ \\
Active & 0.954 & $\mathrm{P}<0.001$ \\
Happy & 0.903 & $\mathrm{P}<0.001$ \\
Content & 0.870 & $\mathrm{P}<0.001$ \\
Playful & 0.803 & $\mathrm{P}<0.001$ \\
& Friendly & $\mathrm{P}<0.001$ \\
& Inquisitive & 0.795 & $\mathrm{P}=0.003$ \\
PC 1 & 0.763 & $\mathrm{P}=0.010$ \\
& Lively & 0.702 & $\mathrm{P}=0.013$ \\
& Calm & 0.687 & $\mathrm{P}=0.021$ \\
& Positively Occupied & 0.652 & $\mathrm{P}=0.034$ \\
& Fearful & -0.610 & $\mathrm{P}=0.003$ \\
\hline Bored & -0.769 & $\mathrm{P}=0.006$ \\
& Apathetic & 0.738 & $\mathrm{P}=0.007$ \\
& Frustrated 2 & $\mathrm{P}=0.009$ \\
& Uneasy & 0.729 & $\mathrm{P}=0.003$ \\
\hline
\end{tabular}

\section{Conclusions}

This study assessed the welfare of dairy cows kept in pastures, using measures of cows' body condition, bodily injury, and cleanliness, and highlighted the importance of improving pasture conditions, management, and housing to enable better performance, health, and welfare of the animals. The QBA findings suggest that the management practices impacted on the emotional condition of the cows. It is important to continue investigations and expand the number of measures surveyed to validate the most useful indicators for assessing welfare and to identify the risk factors that affect the cows' welfare.

\section{Acknowledgments}

We would like to thank undergraduate and graduate students who are members of the Research Group on Bioclimatology, Ethology and Animal Welfare (BIOET) at the Federal University of Paraíba
(UFPB) for their collaboration in the research. The authors would like to thank CNPq and CAPES for granting the scholarship (Process: \#141299/20150). We thank Nelma Suyane P. Caetano and Isabela Beatriz G. C. dos Santos for their collaboration in organizing the data.

\section{Referências}

Andreasen, S. N., Wemelsfelder, F., Sandøe, P., \& Forkman, B. (2013). The correlation of Qualitative Behavior Assessments with Welfare Quality ${ }^{\circledR}$ protocol outcomes in on-farm welfare assessment of dairy cattle. Applied Animal Behaviour Science, 143(1), 9-17. doi: 10.1016/j.applanim.2012.11.013

Bran, J. A., Daros, R. R., von Keyserlingk, M. A. G., LeBlanc, S. J., \& Hötzel, M. J. (2018). Cow- and herd-level factors associated with lameness in small-scale grazing dairy herds in Brazil. Preventive Veterinary Medicine, 151(1), 79-86. doi: 10.1016/j. prevetmed.2018.01.006

Broom, D. M., \& Fraser, A. F. (2010). Domestic animal behavior and welfare. Cambridge: CABI Publishing. 
Bruijnis, M. R. N., Hogeveen, H., \& Stassen, E. N. (2013). Measures to improve dairy cow foot health: consequences for farmer income and dairy cow welfare. Animal, 7(1), 167-175. doi: 10.1017/ S175173 1112001383

Burow, E., Thomsen, P. T., Rousing, T., \& Sørensen. J. T. (2013). Daily grazing time as a risk factor for alterations at the hock joint integument in dairy cows. Animal, 7(1), 160-166. doi: 10.1017/S17517311 12001395

Burow, E., Thomsen, P. T., Rousing, T., \& Sorensen, J. T. (2014). Track way distance and cover as risk factors for lameness in Danish dairy cows. Preventive Veterinary Medicine, 113(4), 625-628. doi: 10. 1016/j.prevetmed.2013.11.018

Cardoso, C. S., von Keyserlingk, M. A. G., \& Hötzel, M. J. (2017). Brazilian citizens: expectations regarding dairy cattle welfare and awareness of contentious practices. Animals, 7(12), 89. doi: 10.3390/ani71200 89

Chapinal, N., Barrientos, A. K., Von Keyserlingk, M. A. G., Galo, E., \& Weary, D. M. (2013). Herd-level risk factors for lameness in freestall farms in the northeastern United States and California. Journal of Dairy Science, 96(1), 318-328. doi: 10.3168/ jds.2012-5940

Cook, N. B., Hess, J. P., Foy, M. R., Bennett, T. B., \& Brotzman, R. L. (2016). Management characteristics, lameness, and body injuries of dairy cattle housed in high-performance dairy herds in Wisconsin. Journal of Dairy Science, 99(7), 5879-5891. doi: 10.3168/ jds.2016-10956

Costa, J. H. C., Burnett, T. A., von Keyserlingk, M. A., \& Hötzel, M. J. (2018). Prevalence of lameness and leg lesions of lactating dairy cows housed in southern Brazil: effects of housing systems. Journal of Dairy Science, 101(3), 2395-2405. doi: 10.3168/jds.201713462

Cresswell, E., Remnant, J. G., Butterworth, A., \& Wapenaar, W. (2016). Injection-site lesion prevalence and potential risk factors in UK beef cattle. Veterinary Record, 180(3), 70. doi: 10.1136/ vr. 103778

Ellis, K. A., Innocent, G. T., Mihm, M., Cripps, P., McLean, W. G., Howard, C. V., \& Grove-White, D. (2007). Dairy cow cleanliness and milk quality on organic and conventional farms in the UK. Journal of Dairy Research, 74(3), 302-310. doi: 10.1017/ S002202990700249X
Fleming, P. A., Clarke, T., Wickham, S. L., Stockman, C. A., Barnes, A. L., Collins, T., \& Miller, D. W. (2016). The contribution of qualitative behavioural assessment to appraisal of livestock welfare. Animal Production Science, 56(10), 1569-1578. doi: 10.1071/AN15101

Garcia, P. R. (2013). Sistema de avaliação do bem-estar animal para propriedades leiteiras com sistema de pastejo. Dissertação de mestrado, Escola Superior de Agricultura "Luiz de Queiroz", Universidade de São Paulo, Piracicaba, SP, Brasil.

Hogan, J. P., \& Phillips, C. J. (2008). Nutrition and the welfare of ruminants. Annual Review of Biomedical Sciences, 10(1), 33-50. doi: 10.5016/18068774.2008.v10pT33

Hughes, J. (2001). A system for assessing cow cleanliness. In Practice, 23(9), 517-524. doi: 10.1136/inpract. 23.9.517

Kivling, S. (2012). Effect of grazing and housing system on dairy cows' hygiene, claw and leg health. Master's thesis. Swedish University of Agricultural Sciences, Ultuna, Uppsala, Suécia.

Matthews, L. R., Cameron, C., Sheahan, A. J., Kolver, E. S., \& Roche, J. R. (2012). Associations among dairy cow body condition and welfare-associated behavioral traits. Journal of Dairy Science, 95(5), 2595-2601. doi: 10.3168/jds.2011-4889

Mellor, D. J. (2016). Moving beyond the "five freedoms" by updating the "five provisions" and introducing aligned "animal welfare aims". Animals, 6(10), 59. doi: 10.3390/ani6100059

Popescu, S., Borda, C., Sandru, C. D., Stefan, R., \& Lazar, E. (2010). The welfare assessment of tied dairy cows in 52 small farms in North-Eastern Transylvania using animal-based measurements. Slovenian Veterinary Research, 47(3), 77-82.

R Core Team (2018). R: A language and environment for statistical computing. Vienna, Austria: R Foundation for Statistical Computing. Retrieved from https:// www.R-project.org/

Ranjbar, S., Rabiee, A. R., Gunn, A., \& House, J. K. (2016). Identifying risk factors associated with lameness in pasture-based dairy herds. Journal of Dairy Science, 99(9), 7495-7505. doi: 10.3168/jds. 2016-11142

Rousing, T., \& Wemelsfelder, F. (2006). Qualitative assessment of social behaviour of dairy cows housed in loose housing systems. Applied Animal Behaviour Science, 101(1-2), 40-53. doi: 10.1016/j.applanim. 2005.12.009 
Rushen, J., Haley, D., \& De Passillé, A. M. (2007). Effect of softer flooring in tie stalls on resting behavior and leg injuries of lactating cows. Journal of Dairy Science, 90(8), 3647-3651. doi: 10.3168/jds.2006463

Sadiq, M. B., Ramanoon, S., Shaik Mossadeq, W., Mansor, R., \& Syed-Hussain, S. (2017). Association between lameness and indicators of dairy cow welfare based on locomotion scoring, body and hock condition, leg hygiene and lying behavior. Animals, 7(12), 79. doi: 10.3390/ani711007

Sant'Anna, A. C., \& Paranhos da Costa, M. J. R. (2011). The relationship between dairy cow hygiene and somatic cell count in milk. Journal of Dairy Science, 94(8), 3835-3844. doi: 10.3168/jds.2010-3951

Santos, S. G. C. G., Amorim, M. L. C. M., Almeida, M. E. V., Fidelis, S. S., Fonseca, V. F. C., \& Saraiva, E. P. (2017). Prevalência de injúrias no jarrete de vacas leiteiras em fazendas na Mesorregião do Agreste da Paraíba, Brasil: um estudo de caso. Anais do Congressso Brasileiro de Biometeorologia, Ambiência, Comportamento e Bem-estar Animl, Jaboticabal, São Paulo, Brasil, 7.

Stockman, C. A., Collins, T., Barnes, A. L., Miller, D., Wickham, S. L., Beatty, D. T., \& Fleming, P. A. (2011). Qualitative behavioural assessment and quantitative physiological measurement of cattle naïve and habituated to road transport. Animal Production Science, 51(3), 240-249. doi: 10.1071/ AN10122

Strydom, S., Agenäs, S., Heath, M. F., Phillips, C. J. C., Rautenbach, G. H., \& Thompson, P. N. (2008). Evaluation of biochemical and ultrasonographic measurements as indicators of undernutrition in cattle. Onderstepoort Journal of Veterinary Research, 75(3), 207-213. doi: 10.4102/ojvr.v75i3.96
Vilela, D., Resende, J. C. D., Leite, J. B., \& Alves, E. (2017). A evolução do leite no Brasil em cinco décadas. Revista de Política Agrícola, 26(1), 5-24.

Wagner, K., Brinkmann, J., March, S., Hinterstoißer, P., Warnecke, S., Schüler, M., \& Paulsen, H. M. (2018). Impact of daily grazing time on dairy cow welfare results of the welfare quality ${ }^{\circledR}$ protocol. Animals, 8(1), 1. doi: 10.3390/ani8010001

Welfare Quality $^{\circledR}$ (2009). Welfare Quality ${ }^{\circledR}$ assessment protocol for cattle. Lelystad, Netherlands: Welfare Quality ${ }^{\circledR}$ Consortium.

Whay, H. R., Main, D. C. J., Green, L. E., \& Webster, A. J. F. (2003). Assessment of the welfare of dairy caftle using animal-based measurements: direct observations and investigation of farm records. Veterinary Record, 153(7), 197-202. doi: 10.1136/ vr.153.7.197

Zaffino Heyerhoff, J. C., LeBlanc, S. J., DeVries, T. J., Nash, C. G. R., Gibbons, J., Orsel, K.,... Haley, D. B. (2014). Prevalence of and factors associated with hock, knee, and neck injuries on dairy cows in freestall housing in Canada. Journal of Dairy Science, 97(1), 173-184. doi: 10.3168/jds.2012-6367

Zoccal, R., Alves, E. R., \& Gasques, J. G. (2011). Estudo preliminar contribuição para o plano pecuário. Brasília-DF: Diagnóstico da Pecuária de Leite Nacional - EMBRAPA Gado de Leite. 
